\title{
TOYOTARITY. TERM, MODEL, RANGE
}

\author{
Stanisław Borkowski ${ }^{1^{*}}$ \\ ${ }^{1}$ Institute of Production Engineering, Faculty of Management, Częstochowa University of Technology, \\ Al. Armii Krajowej 19B, 42-201 Czestochowa, Poland \\ * corrensponding author: Tel.: +48 343250 390, e-mail: bork@zim.pcz.p
}

\section{Resume}

The Toyotarity and BOST term was presented in the chapter. The BOST method allows to define relations between material resources and human resources and between human resources and human resources (TOYOTARITY). This term was also invented by the Author (and is legally protected). The idea of methodology is an outcome of 12 years of work.

Available online on April 2013: http://www.qpij.pl/

\section{Article info}

Article history:

Received 08 June 2013

Accepted 02 September 2013

Keywords:

Toyotarity,

Toyota management principles, BOST

ISSN 2353-5156
1. TOYOTARITY - term, model and elements

„Toyotaism is a term introduced by Toyoda Kiichirō. It means philosophy of actions in automotive industry, which included the following elements:

- Delivery of cars for the whole society.

- Improvement of the automotive industry.

- Production of cars for reasonable price.

- Acknowledgement of sale's significance for development of production.

- Establishment of raw material base (TAIICHI OHNO 2008).

TOYOTARITY is a notion invented by the author of this book and legally protected by date confirmation (BORKOWSKI S. 2012a).

The above document contains the following definition of TOYOTARITY:

Toyotarity is a scientific discipline examining human - machine and human human relationships with consideration of a process-based approach, Japanese culture, especially of the Toyota, oriented to continuous improvement with use of knowledge.

This definition details two dipoles: human - machine and human - human. Human appears in three out of four components of the above definition thus underlining meaning of a human in a Japanese culture and consequently in the culture of Toyota. In the fundamental dipole human-machine, human pole means: originators, initiators, investors, chief management, leaders, who plan and realize human activity. In the other dipole human - human, one pole means: management, leaders - managerial staff, who during performance of human resources management has visual contact with them, it can be stated that they look into eyes of executors of processes, who are an element of the second pole of the human - human relationship.

The basic version of TOYOTARITY model is presented in the figure 1 , while in the figure 2. depicts model of TOYOTARITY with consideration of a process-based approach.

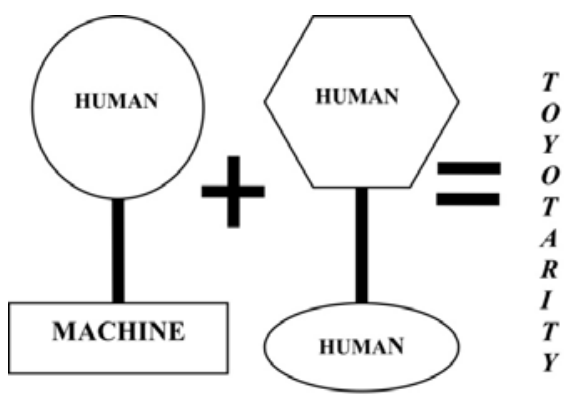

Fig. 1. Basic model of TOYOTARITY

Production Engineering Archives 1 (2013) 


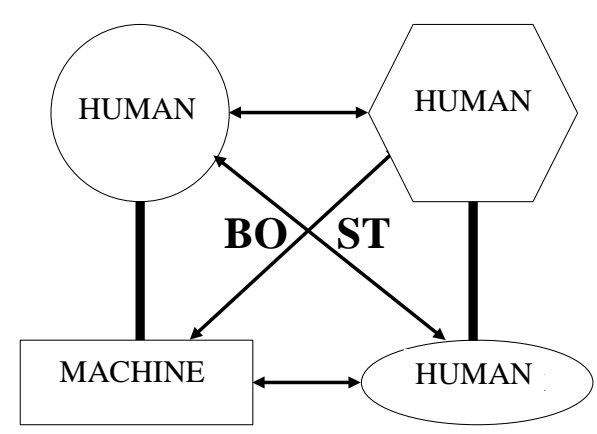

Fig. 2. Model of TOYOTARITY with consideration of a process-based approach

Selection of plane figures is not random:

- Circle as a symbol of a human in the humanmachine dipole underlines significance of this group of people in organizing and functioning of an enterprise, companies providing services etc. Circle emphasises the fact, that this element of TOYOTARITY needs to treat all the elements of organization equally and to know exactly, what is going on around such organization (market behaviour, competition). Human is a mental shortcut of initiators organizing economic activities, investors, chief management, management on a strategic level, owners.

- The second element of analyzed dipole machine is presented as a rectangle, geometric figure with sharp corners, which can be associated with danger, something severe. Such are the historical premises for the notion of machine. In the above model machine means organization's material resources, including machines and devices. Significance of machines in management according to Toyota is underlined in a note of a Polish publisher (TAIICHI OHNO 2008).

Selection of plane figures of the second dipole of the TOYOTARITY notion can be justified in the following way: human - placed in a hexagon, honeycomb. This shape was created by living creatures. Honeycomb cell (its section has a shape of hexagon) fulfils two functions:

- It is a place of birth.

- It is a food container.

Similarly in economic activity this group is responsible for initiating birth of ideas, improvements. At the same time it collects (stores) Production Engineering Archives 1 (2013) information about processes by making appropriate decisions or by transferring them higher to its superiors. Label human in this case means operational management.

The second pole of analyzed dipole is human, inscription placed in a ellipse. This geometric figure has two focal points, symbolizing two elements in operators' work in the model. One element is conduct strictly according to procedures, information acquired during courses and trainings. This element/approach leads to routine in work. In fact, basing on procedural requirements an operator should in the course of time improve scope of his activities. It means continuous "moving" between focal points of this ellipse, because improvement becomes a standard in the course of time.

\section{Toyota production system (TPS)}

Toyota Production System (TPS) is based on scientific principles, which was confirmed in the next years. To sum up, it needs to be underlined that:

- The Toyota's management style has its origins in textile industry.

- Management in reference to automotive industry has elements of an American management (BORKOWSKI S. 2012b BORKOWSKI S. 2012c) with consideration of a Japanese culture.

- The Toyota's management style is based on scientific grounds.

- Management in the Toyota style applies not only to industry but also to services.

Toyota management principles structure is following:

\section{Section I. Long-Term Philosophy}

Principle 1. Base your management decisions on a long-term philosophy, even at the expense of short-term financial goals.

\section{Section II. The Right Process Will Produce the} Right Results

Principle 2. Create a continuous process flow to bring problems to the surface.

Principle 3. Use "pull" systems to avoid overproduction. 
Principle 4. Level out the workload (heijunka)

Principle 5. Build a culture of stopping to fix the problems, to get quality right the first time.

Principle 6. Standardized tasks and processes are the foundation for continuous improvement and employee empowerment.

Principle 7. Use visual control so that no problems are hidden.

Principle 8. Use only reliable, thoroughly tested technology that serves your people and processes.

Section III. Add Value to the Organization by Developing Your People and Partners

Principle 9. Grow leaders who thoroughly understand the work, live the philosophy, and teach it to others.

Principle 10. Develop exceptional people and teams who follow your company's philosophy.

Principle 11. Respect your extended network of partners and suppliers by challenging them and helping them improve.

\section{Section IV. Continuously Solving Root Problems Drives Organizational Learning}

Principle 12. Go and see for yourself to thoroughly understand the situation. (genchi genbutsu).

Principle 13. Make decisions slowly by consensus, thoroughly considering all options; implement decisions rapidly (nemawashi).

Principle 14. Become a learning organization through relentless reflection (hansei) and continuous improvement (kaizen).

The Toyota Production System bases on assumption, that all separate elements work well for the benefit of the entirety. One of its main goals is also supporting and encouraging employees to continuously improve their work. (LIKER J.K. 2005).

\section{Characteristic of BOST method}

The BOST method (this name derives from the first two letters of the author's surname and name, it is legally protected, BORKOWSKI S. 2012a) describes the Toyota's management principles with its characteristic factors. Their number depends on scope of such principle and varies between 4 and 10. Set of factors is called an area. Some principles are divided into two or even three areas. The Toyota's management principles are divided into four sections, while the BOST questionnaire has two versions: version for employees and version for superiors. Version for employees contains set of factors describing principles: $1 ; 2 ; 3 ; 4 ; 6 ; 7 ; 14$ and elements of roof of the Toyota's house (quality, costs, lead time, safety, morale of personnel). Version for superiors contains set of factors describing all the Toyota's management principles and elements of roof of the Toyota's house. Presented questionnaire has a ranking scale. Respondents may assess significance of a given factor by placing one of numbers within the range of scale in an appropriate box.

After description of the main part of the BOST method its further elements will be outlined briefly.

The BOST method allows to:

- Assess significance of factors describing 14 Toyota's management principles

- Styles of management (with consideration of the Toyota's optimum).

- Leadership qualities of managers.

- Satisfaction of employees/customers.

- Commanding qualities of managers.

- Influence of managers.

- Perform team and self assessment.

- Create matrix 3x3 (competitiveness of a product/service, technological possibilities).

- Reputation of a manager.

- Significance of driving forces of improvement.

- Significance of factors allowing for achievement of goals.

- Acquire information about the structure of human potential with focus on: gender, education, age, seniority, mobility, type of employment.

Having considered Marx's principle concerning communicatively of expressions the 
BOST survey was prepared for enterprises, hospitals, offices, shops, schools.

\section{Conclusions}

It should be underlined that the BOST survey also fulfils training functions. Toyota's management principles in the author's researches were described with appropriate set of factors. Selection of factors took few years of work, because they have to be clear for respondents/employees. Choice of individual features of respondents and their variants was also difficult. In the end the following features were chosen: gender (2), education (4), age (7), seniority (8), mobility/number of employers (6) and type of employment (3). They were used to determine structure of human resources, they are also exogenous variables (independent). Numbers in brackets represent numbers of variants. Apart from the Toyota's principles described with applied factors and respondents' features the set of research problems also contains elements of roof of the Toyota's house, which describe mission of enterprises.

\section{References}

[1] BORKOWSKI S. 2012a. Dokumenty zawierajace wymyślony termin (TOYOTARYZM) oraz zawierajace nazwe $i$ strukture opracowanej metody (BOST). Potwierdzenie daty. „AAK” KANCELARIA PATENTOWA s.c. Częstochowa.

[2] BORKOWSKI S. 2012b. Zasady zarzadzania Toyoty w pytaniach. Wyniki badań BOST. Wydawnictwo PTM. Warszawa.

[3] BoRKOWSKI S. 2012c. Toyotaryzm. Wyniki badań BOST. Wydawnictwo PTM. Warszawa.

[4] KonstanciaK M., BorkOWSKi S., JagusiaK M. 4/2011. Supervisors' Assessment According to BOST Method in Chosen Polish Company. Communications. ISSN 1335-4205.

[5] LiKeR J.K. 2005. The Toyota Way. 14 Principles of management of the world's leading manufacturing company. Publisher MT Business. Warsaw (Polish).

[6] TAIICHI OHNo 2008. Toyota Production System: More than the production on a large scale. Publisher ProdPress.com. Wrocław (Polish)3 